\title{
Consult, Consent, and Veto: International Norms and Canadian Treaties
}

Shin Imai

Osgoode Hall Law School of York University, simai@osgoode.yorku.ca

Source Publication:

The Right Relationship

Follow this and additional works at: https://digitalcommons.osgoode.yorku.ca/scholarly_works

Part of the Courts Commons, Indian and Aboriginal Law Commons, and the International Law Commons

(1) $(9)$

This work is licensed under a Creative Commons Attribution-Noncommercial-No Derivative Works 4.0 License.

\section{Recommended Citation}

Imai, Shin. "Consult, Consent and Veto: International Norms and Canadian Treaties." In The Right Relationship, ed. Michael Coyle and John Borrows. (Toronto: University of Toronto Press, 2017).

This Book Chapter is brought to you for free and open access by the Faculty Scholarship at Osgoode Digital Commons. It has been accepted for inclusion in Articles \& Book Chapters by an authorized administrator of Osgoode Digital Commons. 
[Note: this is a draft of a chapter that will appear in Michael Coyle and John Borrows, ed. The Right Relationship, (Toronto: U of $T$ Press - forthcoming. Please feel free to send in comments or correct errors.]

\section{Consult, Consent, and Veto: International Norms and Canadian Treaties}

Shin Imai ${ }^{1}$

In 2007, the United Nations Declaration on the Rights of Indigenous Peoples validated the necessity of obtaining free, prior, and informed consent before instituting significant extractive industry projects on Indigenous lands. The most surprising development since the declaration's adoption is the take-up of the standard by non-state private sector actors. International institutions such as the International Finance Corporation of the World Bank, the financial institutions that have adopted the Equator Principles, and the International Council on Mining and Metals have published policies accepting the necessity of obtaining free, prior, informed consent. In Canada, private sector actors have also recognized the consent standard, including the Prospectors and Developers Association of Canada and a grouping of industry, financial institutions, and

${ }^{1}$ I would like to thank Sally Kang for research assistance and Kent McNeil Jesse McCormick and Jim Reynolds for making suggestions on the text. 
First Nation organizations called the Boreal Forest Initiative. Obviously, adopting some version of the consent standard makes practical and financial sense to the industry.

The courts in Canada have dealt with extractive projects on traditional Indigenous land using a different framework. Rather than requiring consent, Canadian courts require that the Crown consult and accommodate the interests of Indigenous groups. Where treaty rights or Aboriginal rights are infringed, the courts require that the Crown justify the infringement through a test developed in $R . v$ Sparrow, which will be described in part two. Judges have said repeatedly that Indigenous groups in Canada do not have a "veto" over development.

In this chapter I will look at the international consent standard with a view to developing a conceptual framework for its adoption in interpreting the "numbered treaties." Eleven such treaties were signed between 1871 and 1929, and they cover a great deal of our country, spanning First Nation territories from Ontario to parts of British Columbia and north to the Northwest Territories. These treaties provide for the creation of small reserves for the Indians and the "surrender" of the remaining tracts of land to the Crown. The land that is "surrendered" continues to be available for Indigenous hunting, fishing, and harvesting activities. However, once the land is "taken up" by the provincial Crown for activities such as mining, lumbering, and settlement, the treaty rights to hunt, fish, and harvest are suppressed. I will argue that the provincial Crown does not have a unilateral right to "take up" lands; rather, the Crown should obtain the consent of the First Nations concerned before authorizing extractive activity on traditional territories.

In the argument that follows, I refer to documents created at the international level. However, I do not use these in the same way as my colleague Sara Seck. In her 
chapter, she places these instruments in a transnational governance context and looks at the treaties between First Nations and the Crown in the international sphere. By contrast, I am looking at how to use these international instruments can be used by courts in Canada to benchmark Crown and private company conduct in relation to the use of traditional Indigenous territory. My argument is not that the international instruments are binding or persuasive qua international law but rather that they are evidence of best practices in industry that should be incorporated into the development of the common law here. Sara Seck's approach and my approach are different but complementary.

\section{Consent and the "Numbered Treaties"}

The Crown entered into the numbered treaties with Indigenous peoples in order to ensure peace and goodwill with settlers who wished to enter the "tract of country" inhabited by the Indians. The treaties clearly state that the objective was "to obtain consent" of the Indians. ${ }^{2}$ The necessary implication is that the Crown recognized that there was an Indigenous party to the treaty that could, through internal deliberations, decide to give - or withhold - consent. The three elements of the legal framework at the time, then, was that there was an Indigenous collectivity, that it had an interest in the land, and that consent of that collectivity was necessary in order for the Crown to access their territory. ${ }^{3}$

${ }^{2}$ The James Bay Treaty - Treaty No. 9 (Made in 1905 and 1906) and Adhesions Made in 1929 and 1930 (1931; repr., Ottawa: Queen's Printer and Controller of Stationery, 1964), at http://www.aadncaandc.gc.ca/eng/1100100028863/1100100028864\#chp5

${ }^{3}$ I am not implying that the legal framework corresponded to the actual practice on the ground. For a general discussion of problems with treaty implementation, see Royal Commission on Aboriginal Peoples, Looking Forward, Looking Back, vol. 1 of the 
Unfortunately, as the treaties were being rolled out between 1871 and 1929, Canada entered into a century-long Dark Ages in its relations with Indigenous peoples. Through the policy of assimilation, legislation was drafted that legalized the theft of regalia, the destruction of totem poles, the forbidding of ceremonies, the taking of children to residential schools, and the appropriation of Indigenous lands. During this period, the legal framework for treaties and its foundation on consent were ignored. The prevailing attitude was articulated in 1929 by a judge in Nova Scotia who found that a 1752 treaty between the British and the Mi'kmaq was not enforceable.

A civilized nation first discovering a country of uncivilized people or savages held such country as its own until such time as by treaty it was transferred to some other civilized nation. The savages' rights of sovereignty, even of ownership, were never recognized. Nova Scotia had passed to Great Britain not by gift or purchase from, or even by conquest of, the Indians but by treaty with France, which had acquired it by priority of discovery and ancient possession; and the Indians passed with it. ${ }^{4}$

So instead of Indigenous nations capable of making treaties, there was a new legal framework based on "savages" who were not capable of land ownership and therefore had nothing to give consent to. It is based on this legal framework that Prime Minister Pierre Trudeau released his White Paper on Indian Policy in 1969. ${ }^{5}$ He proposed to convert reserves into private property and get rid of Indian status, thereby removing legal space for Indigenous collectivities and Indigenous lands.

Final Report of the Royal Commission on Aboriginal Peoples (Ottawa: Supply and Services Canada, 1996) at 176-9.

${ }_{5}^{4}$ R. v Syliboy, [1929] 1 D.L.R. 307 (N.S. Co. Ct.).

${ }^{5}$ Minister of Indian Affairs and Northern Development, Statement of the Government of Canada on Indian Policy (The White Paper,1969) (Ottawa: Queen's Printer, 1969), http://www.aadnc-aandc.gc.ca/eng/1100100010189/1100100010191 


\section{Consultation, Accommodation, and Veto}

A powerful blowback from First Nations against the White Paper policy, and a Supreme Court of Canada decision in 1973 that opened the possibility of Aboriginal title, ${ }^{6}$ started to roll back this policy of legal annihilation. Judicial recognition of Indigenous peoples was propelled by the enactment of section 35(1) of the Constitution Act, 1982: "The existing aboriginal and treaty rights of the aboriginal peoples of Canada are hereby recognized and affirmed."7

In 1985 the Supreme Court of Canada said that Canada should honour the promises made by the Crown in the written versions of the treaties, ${ }^{8}$ then went further in 1999 to reinterpret the written versions of a treaty to take into account Indigenous perspectives. $^{9}$ In 2005, the Supreme Court of Canada turned its attention to the interpretation of one of the most important clauses in the numbered treaties, and the clause that is central to the argument in this chapter:

And Her Majesty the Queen HEREBY AGREES with the said Indians that they shall have right to pursue their usual vocations of hunting, trapping and fishing throughout the tract surrendered as heretofore described, subject to such regulations as may from time to time be made by the Government of the country, acting under the authority of Her Majesty, and saving and excepting such tracts as may be required or taken up from time to time for settlement, mining, lumbering, trading or other purposes. ${ }^{10}$

${ }^{6}$ Calder v British Columbia (Attorney General), [1973] SCR 313.

${ }^{7}$ Part II of the Constitution Act, 1982, being Schedule B to the Canada Act 1982 (U.K.), 1982 c. 11.

${ }^{8}$ R. v Simon, [1985] 2 SCR 387.

${ }^{9}$ R. v Marshall, [1999] 3 SCR 456.

${ }^{10}$ Treaty No. 8 Made June 21, 1899 and Adhesions, Reports, Etc. (1899; repr., Ottawa: Queen's Printer and Controller of Stationery, 1966), at http://www.aadncaandc.gc.ca/eng/1100100028813/1100100028853\#chp4. 
In Mikisew Cree Nation v Canada (Minister of Canadian Heritage), ${ }^{11}$ the Canadian government approved the construction of a winter road through the Wood Buffalo National Park which would cross the trap lines of over a dozen families who resided near the proposed road, and would affect up to 100 Cree hunters. The First Nation argued that the road infringed its hunting and fishing rights under Treaty No. 8 and relied on the part of the clause that said that Indians could "pursue their usual vocations of hunting, trapping and fishing throughout the tract surrendered."

The Crown, on the other hand, relied on a different part of the same clause - the part that says that lands could be "taken up" for settlement, mining, lumbering, trading or other purposes. They argued that the text of the treaty did not say that the Crown needed to ask permission to take up the lands and did not put any limits on how much land could be taken up. Therefore, Indians had the right to hunt and fish only until the Crown exercised its unilateral right to take up the lands.

The Court did not accept the Crown's interpretation of the clause. Rather, the Court incorporated Aboriginal understandings and found that the Crown did not have an unlimited, unilateral right to take up lands. This approach brought the Court to look at how the lands taken up clause would evolve over time, and divided the taking up of land into two stages. At the first stage, only consultation and accommodation would be required for taking up lands. ${ }^{12}$ At the second stage, when so much land was taken up that "no meaningful right to hunt exists over its traditional territories," ${ }^{13}$ the Crown would

${ }^{11}$ Mikisew Cree Nation v Canada (Minister of Canadian Heritage), [2005] 3 SCR 388.

${ }^{12}$ Ibid, para 55.

${ }^{13}$ Ibid, para 48. See also, Keewatin v Ontario (Natural Resources), 2014 SCC 48, para 52. 
have to do more than consult: it would have to justify its actions using the test developed in $R . v$ Sparrow in $1990 .^{14}$

The "Sparrow test" came to be when Ronald Sparrow went fishing for food in an area traditionally used by his First Nation. He was charged under the federal Fisheries Act for using a net that was longer than that permitted by fisheries regulations. The Supreme Court of Canada found that the regulation could not be permitted to interfere with Sparrow's Aboriginal right to fish for food and ceremonial purposes. In the course of the decision, the Court set out the connection between Aboriginal rights and Crown regulation in a two-part test. First, if the Crown law infringed an existing Aboriginal right, the law would have to have a "compelling and substantial purpose." The example used in Sparrow for an appropriate law would be a regulation aimed at conservation of a resources used by the First Nation. Second, the Crown needed to act honourably and justify the infringement by consulting with the First Nation about the legislation, infringing the Aboriginal right as little as possible and, where appropriate, providing compensation.

This "infringe-and-justify" framework has been applied in hundreds of cases dealing with the numbered treaties at various levels of court and has resulted in limiting the area of land available to exercise treaty hunting, trapping and fishing rights. In the legal framework as articulated in Mikisew Cree and Sparrow there is a right to be consulted, but the role of consent is not developed, as we will see in later in this chapter.

Having dealt with "consultation" I next address the origin of the concepts of "accommodation" and "no veto". In this chapter, I am talking about rights enshrined in

\footnotetext{
${ }^{14}$ R. v Sparrow, [1990] 1 SCR 1075.
} 
historical treaties that embody an agreement between the Crown and the First Nation. However, there has been a parallel development of law in regions of Canada where treaties were never signed, and First Nations assert inherent Aboriginal rights to land. Given the length of time to prove the existence of Aboriginal rights to land in court, Indigenous people argued that they needed to halt development in the interim. The Crown responded that until a court had decided on the existence of Aboriginal title, the Crown could continue resource development. In Haida Nation v. British Columbia, ${ }^{15}$ the Supreme Court of Canada rejected the Crown's argument and found that in such cases the Crown had a duty to "consult and accommodate". There have been hundreds of cases based on Haida Nation. To summarize broadly, the cases say that the Crown must engage with Indigenous groups and try to address concerns that they raise. Indigenous parties must participate in the process and exchange information. Whether the process of consultation and the substantive accommodations proposed by the Crown or project proponents is sufficient to meet the legal standard is up to the courts. If a court finds that the Crown has met the standard to consult and accommodate, then the project can proceed. If the standard is not met, the Court may impose conditions or may require further consultation and accommodation. Many of these cases mention that the First Nation does not have a veto. ${ }^{16}$ In this context, "no veto" means that the final decision on whether the project proceeds does not lie in the hands of the Indigenous group, but rather in the hands of the Court. To look at the issue from the Crown or project proponent perspective, the fact that Indigenous groups have "no veto" does not mean that the project

\footnotetext{
${ }^{15}$ Haida Nation v. British Columbia (Minister of Forests), 2004 SCC 73.

${ }^{16}$ For example, see Behn v Moulton, Contracting Ltd., 2013 SCC 26, para 29.
} 
will necessary go ahead. The Court will determine whether the procedural and substantive standards have been met.

I will return to the discussion of "no veto" in the next section, where I discuss the relationship between the concept of veto and the concept of consent.

\section{Consent, the United Nations Declaration on the Rights of Indigenous Peoples and Voluntary Industry Codes}

At the international level, developments on relations between states and Indigenous peoples began with an assimilationist approach evident in the Indigenous and Tribal Populations Convention (“ILO 107”) of the International Labour Organization (ILO), adopted in 1957. ${ }^{17}$ ILO 107 was aimed at "integration" of Indigenous people into the majority population, and focused on individual equality rights rather than rights of the collectivity. By the mid-1980s, it became clear that Indigenous peoples themselves did not favour such an approach, and the ILO drafted another convention, ILO 169, named the Indigenous and Tribal Peoples Convention, 1989. ${ }^{18}$ The change from "populations" to "peoples" signaled a change in direction: explicitly recognizing the existence of

${ }^{17}$ International Labour Organization, Indigenous and Tribal Populations Convention, 1957 (No. 107), at http://www.ilo.org/dyn/normlex/en/f?p=NORMLEXPUB:12100:0::NO::P12100_INSTR UMENT_ID:312252. The ILO is a specialized body of the United Nations, made up of representatives of workers, employers, and governments. It was the first organization to have an instrument directed specifically at Indigenous people.

${ }^{18}$ International Labour Organization, Indigenous and Tribal Peoples Convention, 1989 (No. 169), at

http://www.ilo.org/dyn/normlex/en/f?p=NORMLEXPUB:12100:0::NO:12100:P12100_I NSTRUMENT_ID:312314:NO. The requirement to consult in ILO 169 came a year before the Supreme Court of Canada released $R$. v Sparrow, which said that consultation was necessary before infringing Aboriginal rights. Canada has not signed ILO 169, so it has no legal applicability in Canada. 
Indigenous collectivities. ILO 169 went further, requiring that Indigenous people be consulted about resource development on their lands:

[G]overnments shall establish or maintain procedures through which they shall consult these peoples, with a view to ascertaining whether and to what degree their interests would be prejudiced, before undertaking or permitting any programmes for the exploration or exploitation of such resources pertaining to their lands. ${ }^{19}$

The growing international movement for Indigenous rights, led by Indigenous

people, resulted in the enactment of the United Nations Declaration on the Rights of Indigenous People in 2007 (UNDRIP). ${ }^{20}$ This declaration recognized the right of Indigenous peoples to self-determination, the preservation of their cultures, and rights to land in their territories. The provision that is most relevant for this chapter is found in Article 32, which provides that Indigenous people must give their free prior and informed consent (FPIC):

States shall consult and cooperate in good faith with the indigenous peoples concerned through their own representative institutions in order to obtain their free and informed consent prior to the approval of any project affecting their lands or territories and other resources, particularly in connection with the development, utilization or exploitation of mineral, water or other resources. ${ }^{21}$

The Government of Canada's reaction to these provisions was baffling. Canada was one of only four countries in the world to vote against the adoption of UNDRIP in 2007, and in 2014 at the World Conference on Indigenous Peoples, when every nation in the General Assembly endorsed the principles of UNDRIP, Canada stood alone to raise

${ }^{19}$ Ibid, Article 15.2.

${ }^{20}$ United Nations Declaration on the Rights of Indigenous Peoples [UNDRIP] UNGA Res 61/295 (13 September 2007), at http://www.un.org/esa/socdev/unpfii/documents/DRIPS_en.pdf

${ }^{21}$ Ibid, Article 32. 
an objection to the consent standard, because in its view, requiring consent would mean that Indigenous people would have a veto over projects on their traditional lands. ${ }^{22}$

The Government of Canada was sharply out of step with international developments and even domestic developments in the private sector. ${ }^{23}$ In the sections below, I outline the adoption of some sort of consent standard by a number of international and Canadian institutions to illustrate the depth and diversity of support for FPIC. ${ }^{24}$

\section{A. The International Finance Corporation}

The International Finance Corporation (IFC) was established in 1956 to offer investment, advisory, and asset management services with the aim of encouraging private sector development in developing countries. A member of the World Bank Group headquartered in Washington, D.C., the IFC is owned, and its policies are determined by,

${ }^{22}$ Canada's Statement on the World Conference on Indigenous Peoples Outcome Document" (New York, 22 September 2014), at http://www.canadainternational.gc.ca/prmny-mponu/canada_un-canada_onu/statementsdeclarations/other-autres/2014-09-22_WCIPD-PADD.aspx?lang=eng

${ }^{23}$ In October, 2015, a new Liberal government under Prime Minister Justin Trudeau came into power and promised to create more positive policies for Indigenous peoples. At the time of writing, there has not been any clear statement on whether the new government will accept the consent standard.

${ }^{24}$ I am not providing an exhaustive list of relevant instruments, some of which do not mention free, prior, informed consent. For example, the Organization for Economic and Cooperative Development's Guidelines for Multinational Enterprises have not been updated since 2011 and do not set out any standards specifically for Indigenous peoples. See http://mneguidelines.oecd.org/text/. As well, I am not going to focus on different iterations of the consent standard or address the effectiveness (or lack of effectiveness) of the voluntary standards themselves. This chapter outlines the conceptual framework for incorporating consent into the implementation of treaties and is not meant to be an analysis of the standards themselves. For an overall review and critique of these voluntary standards, see Penelope Simons and Audrey Macklin, The Governance Gap (London: Routledge, 2014). 
its 184 member countries. Its current work in over 100 developing countries is meant to create jobs, generate tax revenues, improve corporate governance, and improve environmental performance by providing loans to private sector companies active in emerging markets. ${ }^{25}$

The IFC has published performance standards that loan recipients must follow. These standards provide guidance on how to identify and manage risks and impacts. Performance Standard 7 requires that IFC clients identify adverse impacts on affected Indigenous communities and develop action plans to address these impacts with the participation of those communities. The 2006 version of the performance standards mentioned "free, prior, informed consultation" with Indigenous peoples, but the 2012 version requires free, prior and informed consent. ${ }^{26}$

According to the IFC, the client company must procure FPIC through good-faith negotiation with the affected Indigenous community as well as document (1) the mutually accepted process between the parties for obtaining consent, and (2) evidence of agreement between the parties on the outcome of the negotiations. ${ }^{27}$ The performance standard also directs companies to involve Indigenous peoples' representative bodies and members of the affected communities, including vulnerable groups such as women and youth, and to provide sufficient time for decision-making. ${ }^{28}$

${ }^{25}$ International Finance Corporation (IFC), “About IFC: Overview," at http://www.ifc.org/wps/wcm/connect/corp_ext_content/ifc_external_corporate_site/about $\underline{+ \text { ifc }}$ Peoples," at

${ }^{26}$ International Finance Corporation (IFC), "Performance Standard 7: Indigenous http:/www.ifc.org/wps/wcm/connect/1ee7038049a79139b845faa8c6a8312a/PS7_English 2012.pdf?MOD=AJPERES

${ }^{27} \mathrm{Ibid}$, para 12.

${ }^{28} \mathrm{Ibid}$, para 18. 


\section{B. The Equator Principles}

The Equator Principles provide a risk management framework for determining, evaluating, and managing environmental and social risk in projects. They primarily function to "provide a minimum standard for due diligence to support responsible risk decision-making" 29 and are designed to assist member institutions in their decisions to disburse loans to finance particular projects. Member institutions commit to implementing and honouring the Equator Principles within their internal environmental and social policies, procedures, and standards for financing projects and must not provide project financing or project-related corporate loans where the client/project either will not or cannot comply with the Principles.

The establishment of the Equator Principles has brought social/community standards and responsibility - such as those regarding Indigenous peoples, labour/employment, and consultation with affected local communities - to the forefront within the project finance market. In doing so, they have helped rally support for the convergence and consensus around common environmental and social standards. For instance, multilateral development banks and export credit agencies are increasingly drawing on and applying the same standards as the Equator Principles. ${ }^{30}$

Currently, there are eighty-four members in thirty-five countries. They are among the most important financial institutions in the world, including Banco Santander, Bank of America, JP Morgan Bank, Barclays, and all five of the major banks in Canada. These

${ }^{29}$ Equator Principles, “About the Equator Principles,” at http://www.equatorprinciples.com/index.php/ep3/ep3/38-about/about/195

${ }^{30}$ Ibid. 
institutions cover more than 70 per cent of international project finance debt in emerging markets. $^{31}$

The requirement for "free, prior, informed consent" was instituted in 2013 in "Equator Principles III," a change from the preceding requirement for "free, prior, informed consultation" found in "Equator Principles II.",32

\section{The International Council on Mining and Metals}

The International Council of Mining and Metals (ICMM) was established in 2001 to improve sustainable development performance in the mining and metals industry. It brings together twenty-two mining and metals companies, as well as thirty-three national and regional mining associations and global commodity associations, to address core sustainable development challenges. ${ }^{33}$ Canadian members are Barrick Gold, Goldcorp, Teck, the Mining Association of Canada, and the Prospectors and Developers Association of Canada.

The council's May 2013 position statement, "Indigenous Peoples and Mining," explicitly requires its member companies to "work to obtain the consent of indigenous communities for new projects (and changes to existing projects) that are located on lands traditionally owned by or under customary use of Indigenous Peoples and are likely to

31 Ibid.

${ }^{32}$ Equator Principles, “The Equator Principles III - 2013,” at http://www.equatorrinciples.com/index.php/ep3.

${ }^{33}$ International Council on Mining and Metals, "About Us," at http://www.icmm.com/about-us/about-us 
have significant adverse impacts on Indigenous Peoples." ${ }^{34}$ This is a significant shift from the prior position, which required only consultation. ${ }^{35}$

\section{Akwé: Kon Guidelines}

The United Nations Convention on Biological Diversity came into force in December 1993. It promotes "the conservation of biological diversity, the sustainable use of its components, and the fair and equitable sharing of benefits arising from the use of genetic resources. ${ }^{, 36}$ One part of the Convention addresses traditional knowledge of Indigenous people. In order to ensure that traditional knowledge was included in cultural, environmental, and social impact assessments, the members of the Convention developed the Akwé: Kon Guidelines in 2012. These guidelines state that consultations with Indigenous groups should include a way for the local and Indigenous communities to "have the option to accept or oppose a proposed development that may impact on their community.",37

${ }^{34}$ International Council of Mining and Metals (ICMM), "Indigenous Peoples and Mining: Position Statement" (May 2013), at http://www.icmm.com/document/5433

${ }^{35}$ Sarah A. Altschuller, "ICMM Releases Position Statement on Indigenous Peoples Establishing Commitment to FPIC," Corporate Social Responsibility and the Law (30 May 2013), at http://www.csrandthelaw.com/2013/05/30/icmm-releasesposition-statement-on-indigenous-peoples-establishing-commitment-to-fpic/

${ }^{36}$ Convention on Biological Diversity, "History of the Convention," at https://www.cbd.int/history/.

${ }^{37}$ Convention on Biological Diversity, Article 8(e) in "Akwé: Kon Guidelines," at https://www.cbd.int/doc/publications/akwe-brochure-en.pdf. 


\section{E. The Boreal Leadership Council}

The purpose of this Canadian organization is to establish "a network of large interconnected protected areas covering about half of the country's Boreal Forest and the use of leading-edge sustainable development practices in remaining areas." ${ }^{38}$ The seventeen members of the Canadian Boreal Leadership Council come from the finance sector, Indigenous groups, non-governmental organizations, and the forestry industry. ${ }^{39}$

The council believes that the development of the boreal forest requires the free, prior, informed consent of the Indigenous peoples concerned. In September 2012, the council released "Free Prior Informed Consent in Canada," a guidebook that provides information on best practices for implementing FPIC. ${ }^{40}$ and in 2015 the Council reinforced this policy in "Understanding Successful Approaches to Free, Prior, and Informed Consent in Canada",41

\section{F. Prospectors and Developers Association of Canada}

The Prospectors and Developers Association of Canada (PDAC) is the largest mining body in Canada, with more than 1,200 corporate and 9,000 individual members. It published e3 Plus - A Framework for Responsible Exploration in order to help resource exploration companies improve their social, environmental, health, and safety

\footnotetext{
${ }^{38}$ Boreal Leadership Council, at http://borealcouncil.ca/.

${ }^{39}$ Boreal Leadership Council, "Members," at http://borealcouncil.ca/members/.

${ }^{40}$ Boreal Leadership Council, "Free Prior Informed Consent in Canada," September 2012, at http://www.borealcanada.ca/documents/FPICReport-English-web.pdf

${ }^{41}$ Boreal Leadership Council, "Understanding Successful Approaches to Free, Prior, and Informed Consent in Canada" at http://borealcouncil.ca/wpcontent/uploads/2013/09/FPICReport-English-web.pdf
} 
performance and to comprehensively integrate these three aspects into all their exploration programs. e3 Plus is a voluntary guideline designed to help explorers in their decision-making for exploration projects around the world. ${ }^{42}$

The e3 Plus guidelines say that "the concept of free, prior, and informed consent (FPIC) provides a standard for interaction with indigenous communities."43 As a member of the International Council on Mining and Metals, PDAC has subscribed to the consent requirement as articulated by that organization.

Having reviewed five examples of the use of the consent standard, I turn to reasons why the standard makes sense for such a diverse group of institutions.

\section{Why Does It Make Sense for Financial Institutions and Industry to Require the Consent of Indigenous Peoples?}

Because consult is a lower standard, it would seem to make it easier to go forward with development projects, because the Indigenous party can never say "no.” Getting consent from the community would present another barrier for projects to overcome and would appear to make it more difficult for projects to go ahead. Why would the private sector be in favour of consent?

Part of the answer lies in the fact that the costs of community conflict are significant and can result in serious impacts on companies, including suspensions and

${ }^{42}$ Prospectors and Developers Association of Canada, "About Us," at http://www.pdac.ca/about-pdac/about-pdac

${ }^{43}$ Prospectors and Developers Association of Canada, e3 Plus Principles and Guidance Notes, at 80, at http://www.pdac.ca/docs/default-source/e3-plus--principles/e3-plus-principles-amp-guidance-notes---update-2014.pdf 
closures of projects. The degree of opposition has resulted in violent confrontations across the globe, with thousands of people killed, injured, and raped, and huge losses to companies. ${ }^{44}$ For example, Newmont's U.S. $\$ 4.8$ billion Conga project in Peru faced massive opposition, including general strikes and road blockades. Opposing the mine has come with a heavy price for community members, with five farmers killed during one of the protests and many community leaders injured and beaten. However, Newmont was forced to "voluntarily" suspend operation of the mine, with losses in the hundreds of millions of dollars. ${ }^{45}$ Another example is the Canadian company HudBay Minerals, which purchased a Guatemalan mine that had been riddled with conflict and assassinations throughout its history. The conflicts continued under HudBay's ownership as it tried to evict Indigenous people from the mine site. During one confrontation, a community leader was murdered and others injured. The head of security of the mining company was charged and jailed. HudBay ended up selling the mine for CAD $\$ 176$ million in 2011, shortly after it was sued in Canada for the murder and for the alleged gang rapes of women that had occurred during an earlier eviction carried out by the

${ }^{44}$ For examples of case studies of twenty-two conflicts involving Canadian companies in Latin America, see Working Group on Mining and Human Rights in Latin America, The Impact of Canadian Mining in Latin America and Canada's Responsibility (March 2014), at http://www.dplf.org/sites/default/files/report_canadian_mining_executive_summary.pdf

See also Justice and Corporate Accountability Project, The Canada Brand: Violence and Canadian Mining in Latin America (October, 2016), at https://justiceproject.org/the-canada-brand-violence-and-canadian-mining-companies-in-latin-america/

${ }^{45}$ Mining.com, "Peru Abandons Newmont's \$4.8 Billion Conga Project," 28 August 2012, at http://www.mining.com/peru-abandons-newmonts-4-8-billion-congaproject-66180/; Earthworks, "Mining Giant Newmont Urged to Obtain Community Consent," 25 April 2013, at

https://www.earthworksaction.org/media/detail/mining_giant_newmont_urged_to_obtain _community_consent\#.VJXxiP8OjA 
mine's previous owners. ${ }^{46}$ HudBay had bought the mine three years before, for CAD $\$ 446$ million.

In northern Ontario, a conflict between the Kitchenuhmaykoosib Inninuwug First Nation and a junior mining company called Platinex would have turned out better for all parties concerned had consent been the standard. ${ }^{47}$ In this case, the First Nation had been asking for a moratorium on mining activity in the area since 2001 and insisted that drilling not commence until there had been compliance with the First Nation's Development Protocol, which included a referendum in the community. In August 2005, when Platinex announced its plan to begin exploration, the First Nation sent a strong letter of objection. In October 2005, Platinex began raising $\$ 1$ million by selling shares not mentioning the August letter of objection and, instead, telling investors that the First Nation had given verbal consent. In February 2006, Platinex sent in a drilling team without informing the First Nation. A confrontation occurred with members of the First Nation, and the drilling team left. Platinex then launched a law suit for $\$ 10$ billion against the Kitchenuhmaykoosib Inninuwug. This was approximately $\$ 10$ million for every man, woman, and child on the reserve. The First Nation asked for an injunction to stop drilling.

In July $2006,{ }^{48}$ Justice G.P. Smith ordered that drilling be halted in order to permit consultation and negotiations to take place. Over the next few months, the Ontario

${ }^{46}$ For a history of the El Estor mine, see Shin Imai, Bernadette Maheandiran, and Valerie Crystal, "Access to Justice and Corporate Accountability: A Legal Case Study of HudBay in Guatemala" (2014) 35 (2) Canadian Journal of Development Studies 286303.

${ }^{47}$ For a description of this case, see Rachel Ariss and John Cutfeet, Keeping the Land: Kitchenuhmaykoosib Inninuwug, Reconciliation and Canadian Law (Blackpoint, NS: Fernwood, 2012). $2006]$.

${ }^{48}$ Platinex Inc. v Kitchenuhmaykoosib Inninuwug [2006] OJ No. 3140. [Platinex 
Ministry of Mines and Northern Development joined in the negotiations and appeared at subsequent hearings to support Platinex. Various proposals were made to the First Nation with respect to employment, future consultation, a community fund, and fees for negotiation and litigation. The First Nation refused to consent and objected to the fact that Platinex and the ministry demanded that the First Nation agree to the drilling before they would enter into substantive consultations. A year passed and by 1 May $2007,{ }^{49}$ the judge decided that the balance of convenience had shifted and drilling for phase one was allowed to proceed.

At a hearing on 18 May $2007,{ }^{50}$ the judge ruled that an agreement reached between the ministry and Platinex, without the consent of the First Nation, was satisfactory and should be imposed on the First Nation. When the First Nation continued to block exploration activity, the judge found that the chief and the majority of the members of the elected council were guilty of contempt of court. At the urging of a lawyer for the Ontario government, who asked that the penalty be harsh enough "to make it hurt," the judge sentenced them to six months in jail. The matter went up to the Ontario Court of Appeal, and the chief and councillors were released after spending two months in jail. $^{51}$

Platinex was still determined to proceed, and in August 2009 another attempt was made to land a floatplane to begin exploration. The plane was prevented from landing by the chief. Platinex then began negotiating with the Ontario Ministry of Northern

${ }^{49}$ Platinex Inc. v Kitchenuhmaykoosib Inninuwug [2007] 3 CNLR 181.

${ }^{50}$ Platinex Inc. v Kitchenuhmaykoosib Inninuwug [2007] OJ No. 2214.

${ }^{51}$ Platinex Inc. v Kitchenuhmaykoosib Inninuwug, (2008), 91 OR (3d) 18 (Ont. C.A.). 
Development, Mines and Forestry and settled for a payment of $\$ 5$ million from the government, far short of the $\$ 10$ billion originally demanded. ${ }^{52}$

Analysing this situation, we can see that all parties suffered: Platinex lost access to its property. Its investors lost - in December 2014, the stock was trading at one cent. ${ }^{53}$ Ontario taxpayers had to pay $\$ 5$ million, and probably more to cover legal fees, to compensate Platinex. The members of the First Nation spent time in jail. ${ }^{54}$

The Platinex case is but one example of a generalized problem. A Harvard University report on company-community conflicts, based on case studies from around the world, found that the absence of opportunity to consent to projects that affect the community was one of the two major issues that precipitate conflict. ${ }^{55}$

The reality of community opposition provides practical reasons to consider obtaining consent, but there is also a theoretical basis for favouring consent in the thinking of those in the Harvard Negotiation Project. For them, power imbalance is counterproductive. In the words of Lawrence Susskind and Jeffrey Cruikshank, "The

${ }^{52}$ Republic of Mining, “K.I. vs. Platinex: A 'Worst Case' Example of Community Relations" (22 September 2011), at http://www.republicofmining.com/2011/09/22/k-ivs-platinex-a-\%E2\%80\%98worst-case\%E2\%80\%99-example-of-community-relationscanadian-business-ethics-research-network $/$

${ }^{53}$ The Globe and Mail, Stock Quote, at http://www.theglobeandmail.com/globeinvestor/markets/stocks/summary/?q=PTX-X\#

${ }^{54}$ Another exploration company, God's Lake Resources, attempted to explore on the territory of the Kitchenuhmaykoosib. In this case, the province accepted that the First Nation would not consent to the exploration and paid the company $\$ 3.5$ million to give up its right to explore. "Ontario Reaches Agreement with Gods Lake Resources," 29 March 2012, at http://news.ontario.ca/mndmf/en/2012/03/ontario-reaches-agreementwith-gods-lake-resources.html

${ }^{55}$ Rachel Davis and Daniel Franks, Costs of Community-Company Conflict in the Extractive Sector (Cambridge: CSR Initiative at the Harvard Kennedy School, 2014) at 16. See also Ciaran O'Faircheallaigh, "International Recognition of Indigenous Rights, Indigenous Control of Development and Domestic Political Mobilisation" (2012) 47 Australian Journal of Political Science 531-45 at 542 where he describes Rio Tinto's promise to seek consent from an Indigenous group in Australia. 
potential parties to a consensus-building effort cannot participate in a relationship in which one party holds all the power. ${ }^{, 56}$ This imbalance may be a disincentive for weaker parties to engage in negotiation because they may believe they have more effective extralegal options or they may believe there is more built-in protection in the adjudicative system. If there is no true consensus, and the more powerful party imposes a solution, even if the solution makes some accommodation for the weaker party, the weaker party will not have made a commitment to the solution. This means that the solution will not be as durable nor proceed with the cooperation of the weaker party. In situations where there is conflict over a mine, it will mean continued conflict.

The problem with the consult standard is that the community feels powerless, because they are powerless. It is difficult for people to trust a process of discussion when they know that no matter what happens, the final decision is not in their hands. It is through recognition of the necessity of consent that the Indigenous community will have power that can be a balance to the superior economic power of the mining company and the superior political power of government.

\section{What Is the Difference between Consent and Veto?}

I have indicated above that Canadian courts have said that Indigenous people do not have a veto and that Canada raised objections to the consent provisions in the United Nations Declaration on Indigenous Peoples at the 2014 World Conference on Indigenous Peoples, saying that a veto . would be incompatible with Canadian law.

${ }^{56}$ Lawrence Susskind and Jeffrey Cruikshank, Breaking the Impasse: Consensual Approaches to Resolving Public Disputes (New York: Basic Books, 1987). 


\section{A. "Veto" at the International Level}

A group of First Nations attending the World Conference expressed outrage at Canada's position and pointed out that the word "veto" does not appear in the UN document. Grand Chief Matthew Coon Come of the Grand Council of the Crees stated bluntly, “The government has never explained what it means by 'veto.' Is a 'veto' absolute? If so, then a 'veto' isn't the same thing as 'consent. ${ }^{57}$ James Anaya, United Nations Special Rapporteur on the Rights of Indigenous Peoples, takes the same position as Coon Come. He says that there is no right to a veto if it means that Indigenous communities can reject any project whatsoever:

When the Special Rapporteur affirms that Indigenous people do not enjoy a right to have a veto in the context of consultation processes, he refers to the proposition that there is absolute power to unilaterally prohibit or impede all proposals and decisions of the state that could affect them, based on whatever justification or no justification at all. In his view, such a proposition is not supportable. To speak of a right to a veto in that sense, in relation to matters that can be in the legitimate interests of not only the Indigenous party but also national society in general is not consistent with the standard of participatory consultation that is incorporated into international norms. ${ }^{58}$

${ }^{57}$ Jenny Uechi, "First Nation Groups Condemn Federal Government's 'Indefensible Attack' on Indigenous Rights at UN Meeting," Vancouver Observer, 25 September 2014, at http://www.vancouverobserver.com/news/first-nation-groupscondemn-federal-governments-indefensible-attack-indigenous-rights-un. See also Roshan Danesh, "Rhetoric matters when discussing First Nations' role in resource decisions" Globe and Mail (December 9, 2016) online: https://beta.theglobeandmail.com/news/british-columbia/rhetoric-matters-whendiscussing-first-nations-role-in-resource-decisions/article33293082/

${ }^{58}$ Declaración pública del Relator Especial sobre los derechos humanos y libertades fundamentales de los indígenas, James Anaya, sobre la "Ley del derecho a la consulta previa a los pueblos indígenas u originarios reconocido en el Convenio No. 169 de la Organización Internacional de Trabajo" aprobada por el Congreso de la República del Perú, 7 de julio de 2010, punto 1 [Public Declaration of the Special Rapporteur on the human rights and fundamental freedoms of indigenous peoples on the "Law on the right to prior consultation of indigenous and original peoples recognized in ILO 169 of the International Labour Organization, 7 July 2010] [unofficial translation by author], at http://www.politicaspublicas.net/panel/re/nws/632-declaracion-consulta-peru.html. See 
Although Anaya does not think that there exists an absolute veto, he goes on to say that Indigenous communities can refuse to grant their consent when a project would have a significant impact.

In those cases in which the impact of a proposal or initiative on the well-being and rights of an Indigenous people is significant, the consent of the Indigenous party, through an agreement, is not only the objective of consultation, but also a necessary precondition for carrying out the proposed measures. ${ }^{59}$

At the international level, then, the debate is not over whether there is a veto or not but over the circumstances in which consent is required. The consent issue was addressed by the Inter-American Court of Human Rights in the case of Pueblo Saramaka $v$ Suriname. ${ }^{60}$ The Saramaka are descendants of escaped slaves and have lived in the rainforest since the seventeenth century. They carved out their own territory, which they were able to protect from intruders until the mid-twentieth century. At that time, the Government of Suriname began displacing the Saramaka for logging and mining. The Saramaka brought a complaint to the Inter-American Court of Human Rights, which released its decision on 28 November 2007. The Court referred to the United Nations Declaration on the Rights of Indigenous People to find that the Saramaka had the right to be consulted and to consent before mineral and forestry development in their territory. ... the Court considers that, regarding large-scale development or investment projects that would have a major impact within Saramaka territory, the State has a

also, Anaya, S. James and Puig, Sergio, Mitigating State Sovereignty: The Duty to Consult with Indigenous Peoples (November 28, 2016). 67 University of Toronto Law Journal ___ (Forthcoming); Arizona Legal Studies Discussion Paper No. 16-42.

Available at SSRN: https://ssrn.com/abstract=2876760

59 Ibid, point 4.

${ }^{60}$ Inter-American Court of Human Rights, Case of the Saramaka People $v$ Suriname (Merits, Reparations and Costs) (27 November 2007) Series C No 82. 
duty, not only to consult with the Saramakas, but also to obtain their free, prior, and informed consent, according to their customs and traditions. ${ }^{61}$

It is fair to say that the precise parameters for identifying when consent is required are still in development. The Inter-American Court itself provides three iterations of the test. The above quote from the 2007 judgment mentions "large-scale development or investment projects" that would have a "major impact within Saramaka territory." Three paragraphs later in the judgment, the court describes the required impact as "a profound impact on the property rights of the members of the Saramaka people to a large part of their territory." 62 In an Interpretive Judgment from 2008, the Court says that consent is necessary when the impact "could affect the integrity of the Saramaka people's lands and natural resources."63

UNDRIP provides specific examples of instances when consent is required from Indigenous peoples: relocation from their lands and territories; ${ }^{64}$ the taking of their cultural, intellectual, religious, or spiritual property; ${ }^{65}$ the taking of "lands, territories and resources which they have traditionally owned or otherwise occupied or used"; $; 6$ and the storage of hazardous materials on Indigenous lands. ${ }^{67}$

The International Financial Corporation's Performance Standard 7 sets out four similar circumstances to trigger free prior informed consent: adverse impacts on lands

${ }^{61}$ Ibid, para 134.

${ }^{62}$ Ibid, para 137.

${ }^{63}$ Inter-American Court of Human Rights, Interpretation of Saramaka Judgment (12 August 2008), Ser C, No 185, 6 [17] (emphasis added). I wish to thank Jackie Hartley $\mathrm{PhD}$ candidate, University of New South Wales, for bringing these differences in wording to my attention.

${ }^{64}$ UNDRIP, supra note 20, Article 10.

${ }^{65}$ Ibid, Article 11.

${ }^{66}$ Ibid, Article 28.2.

${ }^{67}$ Ibid, Article 29.2. 
and natural resources that are subject to traditional ownership or customary use, ${ }^{68}$ relocation from communally held lands; ${ }^{69}$ significant project impacts on critical cultural heritage $;^{70}$ use of cultural heritage, including knowledge, innovations, and practices, for commercial purposes. $^{71}$

In 2012, the Expert Mechanism on the Rights of Indigenous Peoples, an advisory body to the United Nations Human Rights Council, provided a more comprehensive description:

The Declaration on the Rights of Indigenous Peoples requires that the free, prior and informed consent of indigenous peoples be obtained in matters of fundamental importance to their rights, survival, dignity and well-being. In assessing whether a matter is of importance to the indigenous peoples concerned, relevant factors include the perspective and priorities of the indigenous peoples concerned, the nature of the matter or proposed activity and its potential impact on the indigenous peoples concerned, taking into account, inter alia, the cumulative effects of previous encroachments or activities and historical inequities faced by the indigenous peoples concerned. ${ }^{72}$

We can see that a number of formulations for the circumstances when consent is required are being developed at the international level. I do not intend to parse the differences in wording nor analyse the specific circumstances that have been highlighted, as in this chapter, I focus more on the larger trajectory of the need to obtain consent.

${ }^{68}$ IFC, supra note 25 paras 13 and 14.

${ }^{69}$ Ibid, para 15.

${ }^{70}$ Ibid, para 16.

71 Ibid, para 17.

${ }^{72}$ Human Rights Council, Expert Mechanism, Follow-up Report on Indigenous Peoples and the Right to Participate in Decision-Making, with a Focus on Extractive Industries A/HRC/21/55 (16 August 2012), para 22, at http://www.ohchr.org/Documents/HRBodies/HRCouncil/RegularSession/Session21/AHRC-21-55_en.pdf 


\section{B. Canadian Courts and Consent in Aboriginal Title Cases}

We can now turn to decisions of the Supreme Court of Canada, where the focus has been on "infringe and justify" (Sparrow) and the duty to consult and accommodate (Haida Nation) The cases below discuss Aboriginal title claims in situations where there are no treaties. I apply these principles to the treaty context in part seven.

In Delgamuukw v British Columbia ${ }^{73}$ the Supreme Court of Canada approached the concept of consent in the context of Aboriginal title. Chief Justice Lamer noted that arising from the Crown's fiduciary duty towards Aboriginal peoples, "[t]here is always a duty of consultation." He further noted,

The nature and scope of the duty of consultation will vary within the circumstances. In occasional cases, when the breach is less serious or relatively minor, it will be no more than a duty to discuss important decisions that will be taken with respect to lands held pursuant to aboriginal title ... In most cases, it will be significantly deeper than mere consultation. Some cases may even require the full consent of an aboriginal nation, particularly when provinces enact hunting and fishing regulations in relation to aboriginal lands.(emphasis added) ${ }^{74}$

So Delgamuuk tentatively identifies a sphere of activity where consent is required.

However, this case also provides limits on how the First Nation uses Aboriginal title

lands because of the special bond that exists between the nation and the land:

... if occupation is established with reference to the use of the land as a hunting ground, then the group that successfully claims aboriginal title to that land may not use it in such a fashion as to destroy its value for such a use (e.g., by strip mining it). Similarly, if a group claims a special bond with the land because of its ceremonial or cultural significance, it may not use the land in such a way as to

\footnotetext{
${ }^{73}$ Delgamuukw v British Columbia, [1997] 3 SCR 1010.

${ }^{74}$ Ibid, para 168.
} 
destroy that relationship (e.g. by developing it in such a way that the bond is destroyed, perhaps by turning it into a parking lot). ${ }^{75}$

In 2014, the Supreme Court of Canada released its decision in Xeni Gwet'in v British Columbia. $^{76}$ The Court found that the Tsilhqot'in First Nation had Aboriginal title over 1,750 square kilometres (675 square miles) of land in British Columbia, which gave them the right to decide how the land would be used; the right of enjoyment and occupancy of the land; the right to possess the land; the right to the economic benefits of the land; and the right to proactively use and manage the land. ${ }^{77}$ As a general proposition, then, consent of the First Nation would be necessary for government or a company to use Aboriginal title land. However, in a somewhat puzzling move, the Court decided the Crown could dispense with consent if the land was needed for agriculture, mining, lumbering, building of infrastructure, or settlement. In order to override the lack of consent, the Crown would have to comply with the Sparrow test and show, among other things, that there was a "compelling and substantial" purpose for dispensing with consent and that the Crown had consulted with the First Nation. ${ }^{78}$ However, in another puzzling move, although the Crown could override lack of consent from the Tsilhqot'in, it could not do so if it would "substantially deprive future generations of the benefit of the land."79

To summarize where we are so far, we see that Xeni Gwet'in established that the Tsilhqot'in have Aboriginal title and that consent is necessary for using their lands, but

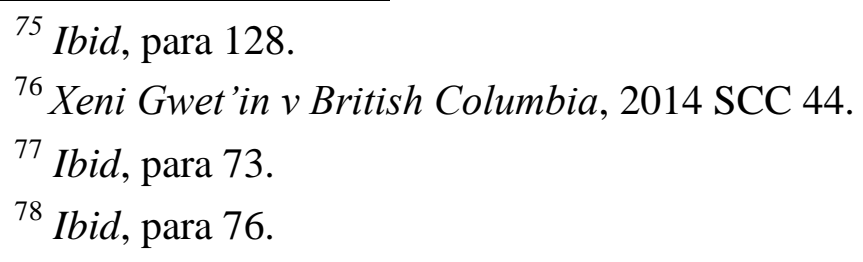


that the requirement for consent could not necessarily prevent agriculture, mining, lumbering, building of infrastructure, or settlement, because the Crown could override the lack of consent using the Sparrow test. However, the Crown override does not apply to projects that would deprive future generations of the benefit of the land, so that the Crown's authority has an outer limit. Does this mean that the Tsilhqot'in themselves can consent to uses that would deprive future generations of the use of the land? Apparently not. Although the Court finds that the Tsilhqot' in can put their lands to use in 'modern ways," the Tsilhqot'ins' land cannot "be developed or misused in a way that would substantially deprive future generations of the benefit of the land." 80 Consequently, it appears that Aboriginal title provides absolute protection of the land for future generations, that cannot be taken away by the Crown using the Sparrow test, nor even by the consent of the First Nation itself. This is starting to look like a Russian doll, with exceptions buried within exceptions.

This Canadian framework is different from the international approach, which protects the sphere of detrimental impact by requiring free, prior, and informed consent by Indigenous people. The international framework, as it has developed so far, has not focused on state power to override the lack of consent by an Indigenous group, but rather has looked at situations where consent is required, and where it is not required.

Both the international and Canadian approaches recognize that there is something special about the link between the land and Indigenous people that needs to be protected. However, the Canadian approach to date fails to provide sufficient agency and recognition to the role of the Indigenous group. The Canadian approach is Crown-centric 
and primarily concerned with Crown conduct in relation to Indigenous people. This is obvious from the questions in the Sparrow test: Is the Crown infringing Aboriginal rights? Is the Crown consulting? Is the Crown acting honourably? The international consent standard, on the other hand, adds a focus on the Indigenous group as well. States have obligations to consult and ensure that there is free, prior, informed consent, and this requirement puts Indigenous groups at the centre of the process in a way that the Sparrow infringe-and-justify test or Haida Nation's consult and accommodate test does not.

In the next section, I will provide some preliminary ideas on how the consent standard could be applied to implement treaties in Canada.

\section{Court Adoption of Best Practices Standards}

While private-sector corporate social responsibility initiatives have helped to bring discussions on consent into the mainstream, these voluntary initiatives generally do not provide any form of redress for individual complaints, and are unenforceable against the companies themselves. As such, in cases where there is an allegation of a breach by one of the signing institutions, the complainant is left with little or no recourse.

For instance, the Equator Principles simply oblige member financial institutions to require any company with whom they deal to establish a grievance mechanism designed to receive and facilitate resolution of concerns about a project's environmental and social performance within the company or project itself. However, the Equator Principles do not impose a duty on its members to adopt grievance mechanisms of their 
own. Consequently, if someone feels that a member bank has lent money for a project that does not have Indigenous consent, there is no avenue for complaining to the bank or the Equator Principles organization. ${ }^{81}$

There are similar problems with the other standards. The e3 Plus guidelines from the Prospectors and Developers Association of Canada are not mandatory for members, and there is no way to determine which, if any, companies have adopted them. The International Council on Mining and Metals (ICMM) makes its guidelines mandatory to its members, but there is no way of complaining if there is a breach. The ICMM website states that if the ICMM office receives a complaint, it will be referred directly to the company; the ICMM itself does not address or mediate issues between a third party and a member. ${ }^{82}$ The Boreal Leadership Council developed its guidelines on free, prior, informed consent to "encourage and contribute to a solutions-based dialogue," council does not police adherence to the guidelines. Similarly, the Secretariat on the UN Convention on Biological Diversity does not police implementation of its Akwé: Kon Guidelines.

Of the organizations whose performance standards are studied in this chapter, only the International Finance Corporation is equipped with a grievance mechanism: the Compliance Advisor Ombudsman (CAO), an independent recourse mechanism for projects supported by the private-sector agencies of the World Bank Group. Indigenous groups can make a direct complaint to this agency rather than the company against whom

${ }^{81}$ For general commentary on the Equator Principles, see Simons and Macklin, supra note $24,142-50$.

82 ICMM, FAQs on Membership Requirements, at http://www.icmm.com/ourwork/sustainable-development-framework/faqs-on-membership-requirements.

${ }^{83}$ Boreal Leadership Council, supra note 38. 
they are making the complaint. However, the CAO merely "responds to complaints from project-affected communities" by "help[ing] parties identify alternatives for resolving the issues of concern." The CAO has explicitly stated that it does not "impose solutions or find fault, $" 84$ so remedies to individuals or enforcement against the company are not within its mandate. ${ }^{85}$

While the consent standards described above do not provide any direct remedies to Indigenous communities, they do give an indication of what some bodies consider to be "best practices" for the industry. The actions of particular government or industry players can be judged against the best practices suggested for the industry in judicial proceedings.

For example, the Akwé: Kon Guidelines of the Convention on Biological Diversity are not directly binding on anyone, but the Inter-American Court of Human Rights took note of the guidelines as a standard for assessing the behaviour of the Government of Suriname in the consultation process in the Saramaka case. The Court called the Guidelines "[o]ne of the most comprehensive and used standards for [Environmental and Social Impact Assessments] in the context of indigenous and tribal Peoples." ${ }^{86}$ Other bodies have referenced, recognized or adopted the Akwé: Kon Guidelines

${ }^{84}$ Office of the Compliance Advisor/Ombudsman, How We Work: Ombudsman, at http://www.cao-ombudsman.org/howwework/ombudsman/.

${ }^{85}$ Although the IFC could technically withdraw funding from a project for failing to comply with the Performance Standards, this has happened only rarely. See Simons and Macklin, supra note 23 130-42.

86 Case of the Saramaka People v Suriname (Interpretation of the Judgment on Preliminary Objection, Merits, Repartions, and Costs) 12 August 2008, Series C No. 185, fn 23. 
as well, including the Kenya Industrial Property Institute, ${ }^{87}$ the UK National Contact Point for the Organization for Economic Cooperation and Development, 88 the Government of Finland ${ }^{89}$ and the Supreme Court of India. ${ }^{90}$

In Ontario, decisions in the two cases referred to the e3 Plus Aboriginal engagement guidelines published by the Prospectors and Developers Association of Canada, although, as I have already indicated, these guidelines are voluntary and even PDAC members are not obliged to follow them. Nonetheless, two courts in Ontario have used them as a touchstone for company behaviour. In Wahgoshig First Nation v Solid

${ }^{87}$ The Traditional Knowledge and Genetic Resources Unit of the Kenya Industrial Property Institute was established in March 2009 to address issues of intellectual property rights relating to traditional knowledge associated with genetic resources for indigenous and local communities practicing traditional lifestyles. In this context, the Unit's work was to also address the Akwé: Kon Guidelines: www.kipi.go.ke/index.php/traditionalknowledge (last accessed July 20, 2016)

${ }^{88}$ In its final statement respecting a complaint brought by Survival International against Vedanta Resources under the OECD Guidelines for Multinational Enterprises, the UK National Contact Point for the OECD Guidelines for Multinational Enterprises included a list of recommendations. Among these was the recommendation that Vedanta immediately and adequately engage with the Indigenous group Dongria Kondh regarding, among other things, the construction of Vedanta's proposed mine. As a guide to pursue the consultation process, the UK National Contact Point recommended that Vedanta refer to the consultation process outlined in the Akwé: Kon Guidelines:

www.oecd.org/corporate/mne/46085980.pdf (last accessed July 20, 2016)

${ }^{89}$ The Government of Finland applied the Akwé: Kon Guidelines in connection with the management and land use planning for the Hammastunturi Wilderness Area, which involved the participation of the Saami people. Finland is the first country to have applied these Guidelines in practice: www.cbd.int/doc/world/fi/fi-nr-oth-en/pdf (last access July 20, 2016)

${ }^{90}$ The Akwé: Kon Guidelines were discussed extensively before the Supreme Court of India in the Sethusamudram case. This case concerned the validity of an environmental impact assessment for the Sethusamudram Shipping Canal Project, which would create a shipping route between Indian and Sri Lanka. The petitioner raised the question of the Akwé: Kon Guidelines. In the end result, the Supreme Court directed the Government of India to consider an alternate shipping route for the project: www.rufford.org/files/EIA\%20Post,\%20VOL\%201,\%20Issue\%201.pdf (last accessed July 20, 2016) 
Gold Resources Corp,${ }^{91}$ Solid Gold, a small exploratory company headquartered in Sudbury, refused to consult with the Wahgoshig First Nation, in spite of its being advised to do so by the Ontario government. When Solid Gold attempted to continue exploring, the First Nation took the matter to court. In granting an injunction against further exploration, Justice Carole Brown wrote, "[I]t ... appears that Solid Gold has failed to meet industry standards for responsible exploration as set forth by the Prospectors and Developers Association of Canada with respect to First Nations engagement."92

Another example is the Platinex Inc. v Kitchenuhmaykoosib Inninuwug First Nation described above. ${ }^{93}$ Justice G.P. Smith, the judge in this case, noted that Platinex did not follow the Prospectors and Developers Association of Canada's Best Practices Exploration and Environmental Excellence Standards, which state that before drilling is to commence on lands under an Aboriginal claim, the drilling company should sign a memorandum of understanding. ${ }^{94}$ This was one of the factors that led the judge to suspend drilling until consultations had taken place.

We see here that some of these voluntary standards have been given life in both international and domestic courts. In the next section I argue that the consent standard from non-binding international and domestic instruments should inform judicial thinking. Why should courts shy away from requiring best practices for resource extraction on Indigenous lands?

${ }^{91}$ Wahgoshig First Nation v Ontario, 2011 ONSC 7708.

92 Ibid, para 59.

${ }^{93}$ Platinex 2006, supra note 48.

${ }^{94}$ Ibid, para 41-3. 


\section{Application of Consent Standard to Numbered Treaties}

As I stated at the beginning of this chapter, I am going to sketch out some preliminary thoughts on a legal framework for consent, building on existing case law. The two elements of the numbered treaties that are relevant to this discussion are the clause dealing with the "surrendering" of traditional territories; and the hunting and fishing "lands taken up" clause. The treaties also created reserves, which are small pieces of land, perhaps fifty square kilometres (twenty square miles), which are under a separate Indian Act legal regime that does not apply here. The lands that are the subject of the analysis in this chapter are large tracts that are covered by the treaty but are outside of the reserves. I refer to these as "treaty lands." The fact pattern I have proposed to explore the legal framework is for extractive industry access to treaty lands (that is, off reserve), not covered by a land claims agreement, not patented (that is, Crown lands), in a rural area.

There are three building blocks to my analysis.

(i) Courts have found that there is an Indian interest in treaty lands in spite of the "surrender clause" and that the Crown has neither unilateral nor unlimited power to take up lands for extractive industry, in spite of the "lands taken up clause." There is a duty to consult and accommodate for any taking up of lands, but in cases where the taking up will impact the meaningful right to harvest, the Crown must justify its actions using the Sparrow test. 
(ii) I argue that there should be negotiations to identify how much land is needed to maintain a meaningful right to harvest. Until there are such negotiations, the courts need to provide a forum for identifying the point in time when the right is threatened.

(iii) The Mikisew Cree case, discussed in part two, dealt with the "taking up" of lands and said that "compelling and substantial" purposes could justify taking away the meaningful right to harvest. I argue that Indigenous consent should now be added to the justification test for future "taking up" of lands.

\section{A. The Surrender Clause and Continuing Indigenous Interest in Traditional Lands}

The fact that the written versions of "numbered treaties" say that the land was "surrendered" to the Crown raises the question of the nature of the Indian interest on lands that are covered by the treaty but are outside of the reserves.

The "surrender" clause in Treaty No. 8, for example, reads like an absolute transfer of title from First Nations to the Crown.

... the said Indians DO HEREBY CEDE, RELEASE, SURRENDER AND YIELD UP to the Government of the Dominion of Canada, for Her Majesty the Queen and Her successors for ever, all their rights, titles and privileges whatsoever, to the lands included within the following limits ... ${ }^{95}$

First Nations say that they never considered the treaties to be real estate deals rather, they were meant to create relationships with the Crown. There is plenty of evidence that in various negotiations, the Indians were told that their livelihoods would

${ }^{95}$ Treaty No. 8, supra note 10. 
not change. In his chapter of this book, Michael Coyle explains the problems arising from the different understandings of the treaties. Although there is some judicial support for questioning the validity of the surrender clause as it is set out in the written version of the treaty ${ }^{96}$ most courts assume that the surrender is valid, and that rights to the land have been alienated. If the surrender is valid, can consent from Indigenous groups be required for the use of land that belongs to the Crown?

For our purposes, I do not think that we need to answer the question of who "owns" the land. Whether or not there was a total surrender of the land, it is not disputed that treaty First Nations have an interest in their traditional lands arising from their traditional use and occupancy of the land. The right to continue to use the land for harvesting purposes is written into the treaty through the "lands taken up" clause. As indicated earlier in this chapter, this clause, if read literally, gives the Crown unlimited unilateral authority to take up lands until there is nothing left for the harvesting activities. The Supreme Court of Canada, however, in Mikisew Cree recognized that the Crown's authority was not unlimited - the First Nation needs enough land to "meaningfully" exercise harvesting rights. Nor could the Crown exercise its authority unilaterally, as the Court imposed a requirement to consult and accommodate the First Nation before taking up the lands.

Canadian law is consistent with the thinking on the nature of Indigenous interest in land at the international level. The United Nations Declaration on the Rights of Indigenous Peoples refers to "lands, territories and resources which they have

${ }^{96}$ See Ka'a'Gee Tu First Nation v Canada (Minister of Indian and Northern Affairs), 2007 F.C. 764. 
traditionally owned or otherwise occupied or used. ${ }^{97}$ The International Finance Corporation Performance Standard 7, which is incorporated into both the Equator Principles and the International Council on Mining and Metals standards, specifically provides for the requirement of consent on lands that are "traditionally owned or under customary use." Legal title or demarcation is not necessary:

Indigenous peoples are often closely tied to their lands and related natural resources. Frequently, these lands are traditionally owned or under customary use. While Indigenous peoples may not possess legal title to these lands as defined by national law, their use of these lands, including seasonal or cyclical use, for their livelihoods, or cultural, ceremonial, and spiritual purposes that define their identity and community, can often be substantiated and documented. ${ }^{98}$

\section{$B$. The Lack of a Forum to Discuss the "Meaningful Right to}

\section{Harvest"}

As we have seen, the Crown is required to consult on, but not justify, taking up lands until the point where there is no longer enough land to "meaningfully" exercise harvesting rights. One of the practical challenges, then, is trying to decide when that point in time is reached. How do we know when a particular project will send us off the edge? Is anyone keeping track?

Individual decisions based on the rights of individuals to hunt or fish, or judicial review of the adequacy of consultations in individual project proposals, do not provide the overview necessary for decision-making bodies to determine whether the taking up of land in a particular treaty area is approaching the point in time when the "meaningful right" disappears. For example, in 2004, the Saulteau First Nations argued that there

${ }^{97}$ UNDRIP, supra note 20, Article 28.2, emphasis added.

${ }^{98}$ IFC, supra note 26 para 13, emphasis added. 
needed to be a study of the cumulative impacts of development because "if approvals are not considered broadly in context, small incremental infringements may threaten treaty rights by 'death by a thousand cuts.' 99 This anxiety is not misplaced, because almost every square centimeter of land in Canada is subject to some type of non-Indigenous interest, ranging from mining concessions and water rights for private companies to rights of way for recreational snowmobilers. Furthermore, there is legislation in the provinces that will permit an automatic "taking up" of treaty lands with no scrutiny or notice whatsoever. For example, the free-entry system for mines in British Columbia allows company to stake claims without obtaining any prior approval from government, ${ }^{100}$ and the Ontario Court of Appeal has upheld provincial legislation that dedicates highways for public use by the passage of time, without requiring any decision on anyone's part. ${ }^{101}$

In spite of these continual creeping encroachments, there is at present no systematic process for gathering information on what rights need to be "meaningfully" protected or how much land needs to be set aside to protect those rights. Ideally, there would be a political negotiation process to address this problem. In an article in 2001, I argued that the treaty lands problem can be resolved only through a process that will set

${ }^{99}$ Saulteau First Nations v British Columbia (Oil \& Gas Commission), 2004 BCSC 92, para 4.

${ }^{100}$ For a description of the free-entry system in Ontario as it existed at the time of the dispute between Platinex and the Kitchenuhmaykoosib Inninuwug, see Rachel Ariss and John Cutfeet, "Kitchenuhmaykoosib Inninuwug First Nation: Mining, Consultation, Reconciliation and Law" (2011) 10 Indigenous Law Journal 1. In Ross River Dena Council v Yukon, 2012 YKCA 14, the court found that the free-entry system in the Yukon was unconstitutional because it did not provide for consultation with affected First Nations.

${ }^{101}$ R. v Jacob (2009), 245 OAC 381. 
aside enough lands to preserve the meaningful right to hunt, fish, and trap. ${ }^{102}$ Such comprehensive negotiations on treaties as a whole were recommended by the Royal Commission on Aboriginal Peoples as far back as in $1985,{ }^{103}$ and by Michael Coyle in his chapter in this book. Without a political framework, however, matters end up in court, and the courts are struggling.

Four cases illustrate how difficult it is to find an appropriate judicial forum to discuss the meaningful right to harvest and operationalize the test in Mikisew Cree.

In the first case, Buffalo River Dene Nation v Saskatchewan (Minister of Energy and Resources), ${ }^{104}$ the question of timing for raising an objection to exploration is the issue. In this case, the Saskatchewan Court of Appeal held that consultation was not required before the issuing of an exploration permit, because there would be no actual impact until a second permit for exploitation was issued. The court reasoned as follows:

To trigger [the duty to consult], actual foreseeable adverse impacts on an identified treaty or Aboriginal right or claim must flow from the impugned Crown conduct. While the test [for consultation] admits possible adverse impacts, there must be a direct link between the adverse impacts and the impugned Crown conduct. If adverse impacts are not possible until after a later-in-time, independent decision, then it is that later decision that triggers the duty to consult. ${ }^{105}$

102 Shin Imai, “Treaty Lands and Crown Obligations: The 'Tracts Taken Up' Provision" (2001) 27 QLJ 1.

${ }^{103}$ Canada, Report of the Royal Commission on Aboriginal Peoples: Restructuring the Relationship, vol. 2 (Ottawa: Supply and Services Canada, 1996), 4654.

${ }^{104}$ Buffalo River Dene Nation v Saskatchewan (Minister of Energy and Resources), [2015] 2 C.N.L.R. 81 (Sask.C.A.). This decision runs counter to a decision by the Yukon Court of Appeal, which decided that the Crown's duty to consult was triggered when a mining claim was registered: Ross River Dena Council v Yukon, 2012 YKCA 14 at para 56.

105 Ibid para 104. 
However, the court failed to appreciate that the exploration stage is not benign. It sets in motion a set of expectations and financial relationships. The court itself notes that the exploration companies must raise money from investors. These investors should know what interests the First Nations will assert if exploitation begins. It is not fair to allow exploration companies to keep investors in the dark. If a First Nation has a strong position against development of resources on a particular part of their territory, investors should know before speculating on the exploration company. Unfortunately, the Buffalo River Dene Nation case does nothing but punt the problem into the future, where the Crown, First Nation and mining company will find themselves deadlocked in the same way that the parties in Platinex were deadlocked: the mining company and investors have made financial commitments and need to move ahead with the project; the First Nation continues to block access to its land; and the Crown must buy themselves out of a political bind using public funds. It is a lose-lose-lose proposition.

The second case deals with the process appropriate for raising the issue of the meaningful right to harvest. In Yahey v British Columbia, ${ }^{106}$ the Blueberry River First Nations (BRFN), which are protected by Treaty No. 8 , commissioned a study that showed development in their traditional territory has resulted in two-thirds of their territory being used for industry or located within 250 metres of an industrial location. At this rate, by 2060 there would be no land left for hunting and fishing activities guaranteed by the treaty. The First Nations asked for an injunction on the sale of certain timber licences. The court denied the injunction on the basis that stopping the particular timber

${ }^{106}$ Yahey v British Columbia, 2015 BCSC 1302 (B.C.S.C.). 
licences would only affect a small portion of the treaty territory, and that the First Nation should seek a general moratorium on all development in the area.

BRFN may be able to persuade the court that a more general and wideranging hold on industrial activity is needed to protect its treaty rights until trial. However, if the court is to consider such a far-reaching order, it should be on an application that frankly seeks that result and allows the court to fully appreciate the implications and effects of what it is being asked to do. The public interest will not be served by dealing with the matters are dealt with on a piecemeal, project-by-project basis. ${ }^{107}$

Prophet River First Nation v British Columbia (Minister of Environment) ${ }^{108}$ raises

the issue of which bodies are obliged to consider whether the meaningful right to harvest is in play. Four Treaty No. 8 First Nations challenged the approval of an environmental assessment for a dam on the Peace River that would have created a reservoir of 9,330 hectares. The First Nation argued that development in the Peace River basin would take away the meaningful right to hunt and therefore, infringe the rights in the treaty. The British Columbia Supreme Court decided that the ministers, in approving the environmental assessment, did not have to take into consideration whether the impact on treaty lands would take away the meaningful right to hunt. Rather, the only obligation was to ensure that there was deep consultation. The court suggested that the larger issues on treaty infringement needed to be raised in an action that would address the issue for the whole territory.

The problem with the "piecemeal" approach for First Nations is that each development, taken in isolation, will not likely constitute treaty infringement. But if First Nations cannot raise these issues in specific cases, they will be left to do what the judge

\footnotetext{
107 Ibid para 64.

${ }^{108}$ Prophet River First Nation v British Columbia (Minister of Environment), [2015] B.C.J. 2026.
} 
suggests - initiate actions for moratoria on all development in treaty territories. One could imagine that courts would be hard pressed to impose such wide-ranging moratoria on development, and one would anticipate a significant backlash from the non-Native population. No such case has ever succeeded in Canada. ${ }^{109}$

In the fourth case that I want to highlight here, the issue was whether consultation was enough to override treaty rights. In Athabasca Chipewyan First Nation v Canada (Minister of the Environment). ${ }^{110}$ an environmental panel found that the Shell Canada Energy Jackpine Mine Expansion in northern Alberta would have extensive irreversible adverse impacts on the land and culture of the First Nation covered by Treaty No. 8 . Nonetheless, the governments decided to proceed with the project after a six-year study that included "deep consultation" with the First Nation. To the extent that this case suggests that a project which will have irreversible impacts on treaty rights can be countenanced simply because there has been "deep consultation" I would suggest the court is applying the wrong test. When there is an infringement of a treaty right, as appears to be the case here, whether the consultation is adequate is the wrong test. It seems to me that in this case, we are dealing not with a consultation problem but, rather, with a problem relating to the infringement of the treaty that would have required the application of the Sparrow test.

At the risk of repeating myself, let me explain where I think that courts have taken us. First, Buffalo River Dene Nation case suggests that First Nations cannot object if the

${ }^{109}$ See Ontario (Attorney General) v. Bear Island Foundation [1991] 2 S.C.R. 570 where the Court lifted a caution placed on the provincial registry for all land in the traditional area of the Bear Island First Nation.

${ }^{110}$ Athabasca Chipewyan First Nation v Canada (Minister of the Environment), 14 FC 1185 (FC). 
exploratory activity does not have an impact on the First Nation. The First Nation must wait until the resource extraction company and its investors have made financial commitments to the project and plan to exploit the resource. Second, the Yahey case makes it impossible to raise the larger issues relating to a meaningful right to hunt in an injunction for specific licences, and Prophet River suggests that the issue cannot be addressed in the environmental assessment process. Third, the Athabasca Chipewyan First Nation case shows that even if the First Nation were able to show treaty infringement, deep consultation would be enough to permit the project to go ahead. So none of these cases permit a discussion of the big picture relating to the meaningful right to harvest. The only option suggested by the courts is to bring a court case to stop all development on their treaty lands. As I have already indicated, this is not a realistic proposition, and judges themselves would likely be taken aback should such a claim ever be made. Certainly, forcing First Nations to make such broad claims would not facilitate reconciliation between Indigenous and non-Indigenous people, but rather invite a harsh backlash.

If these four cases articulate the present law, the courts have closed off a substantive consideration of whether the "meaningful right" described in Mikisew Cree has been infringed. These cases have not attempted to construct a viable framework for assessing when the "meaningful right" to hunt has disappeared. It is clear that a political process is needed to resolve these issues, but is there anything that courts could be doing differently until there are broad negotiations on treaty lands? In my view, courts can make an important contribution. 


\section{Introducing Consent into the Sparrow Test}

I suggest that courts should look at development on treaty lands, not as issues relating to consultation but as issues relating to treaty infringement. In other words, new licences for resource extraction would not be subject to the consultation and accommodation test set out in Haida Nation but, rather, the infringement and justification test set out in Sparrow and Mikisew Cree. By applying the Sparrow test, the courts would look for the Crown to do more than consult. The Crown would have to justify the objectives of the legislation and show that it acted honourably in infringing treaty rights. It is here that the consent standard could be applied. As mentioned above, the Supreme Court of Canada suggested in 1997 in Delgamunkw v. British Columbia, that consent may be necessary where the proposed development would infringe harvesting rights. While courts have not expanded on the concept of consent, I have argued above that international standards and industry practice have overtaken judicial and governmental reluctance to recognize the consent standard. So part of the justification would involve determining whether the infringement was significant enough to require consent.

If the default position were that any resource exploration on treaty lands could potentially take away the meaningful right to harvest, and thereby infringe treaty rights, then the Crown would be forced to enter discussions early with the First Nation to obtain their consent. It may be that some accommodation could be reached for exploratory activities and eventual exploitation. But if there were no accommodation possible, then the mining company and its investors will know before they make irrevocable financial commitments. 
Does this mean that First Nations would have a "veto" on all resource extraction on their lands? Under the present, law, the answer would be "no" because courts will decide, on a case by case basis whether the Crown has justified the infringement of the treaty right and whether consent was obtained. Courts must do this analysis sooner or later in any case, and it is manifestly better to face the problem earlier, rather than later when the parties have more at stake and the losses will be more impactful.

\section{Adoption of the Consent Standard Should Not be Difficult}

I began by describing the three elements of the original legal framework for the numbered treaties: recognition of an Indigenous collectivity; recognition of an interest of the collectivity in their lands; and recognition of the necessity of obtaining consent to access those lands.

After a dark century, where neither government nor courts recognized any of the three elements of the framework, reconstruction began towards the end of the twentieth century. Today, almost two decades into the twenty-first century, recognition of Indigenous collectivities and their interest in their lands is well settled. However, Canadian courts have not yet explicitly started developing a law around consent. Instead, courts in Canada have been focusing on consultation and accommodation and justification of infringement embedded in an overall lack of a "veto" by Indigenous people. I argue in part five that an advantage of the consent standard being developed internationally is that it puts Indigenous people at the centre of the decision on land in a way that the infringe-and-justify framework does not. In this part, I argue that we are on the precipice of losing the meaningful right to harvest, and that there is a legal and moral 
imperative to require consent of First Nations for further taking up of lands. I also point out that in Delgumuukw, the Supreme Court of Canada contemplated the necessity of consent when hunting, fishing, and trapping rights would be taken away.

But my views are also informed by the fact that consent is already the "best practice" for the extractive industries. International state-sponsored institutions such as the United Nations, the Convention on Biological Diversity, the Inter-American Commission of Human Rights, and the International Finance Corporation as well privatesector bodies such as the Equator Principles, the International Council on Mining and Metals, and the Boreal Leadership Council have already adopted the consent standard. The adoption of this standard makes sense both practical and theoretical sense. For the practical utility of the standard, I have given the examples of the high cost of conflict in the multi-billion-dollar Conga project in Peru, now suspended by Newmont, and in Canada, the halting of Platinex's exploratory activities on the treaty lands of the Kitchenuhmaykoosib Inninuwug. For the theoretical advantage of respecting the consent standard, I have pointed to negotiating theory, which suggests that the greater equality of bargaining power that comes with the recognition of the necessity of consent will more likely lead to better and more durable outcomes.

In Canada, recognizing consent is more a conceptual barrier for governments and the courts than an actual practical concern. Industry practice has largely moved to the consent standard in the form of Impact Benefit Agreements (IBAs) - agreements that are negotiated directly between companies and Indigenous communities. In return for a promise from the community not to oppose the project, the company will provide monetary benefits, some training, and perhaps some form of environmental 
monitoring. ${ }^{111}$ In spite of some highly publicized conflicts, like that of the

Kitchenuhmaykoosib, the majority of projects in Canada are able to proceed after IBAs have been signed.

Government, as well, has largely moved to seeking agreements with First Nations on large land claims. The federal and provincial governments were first forced into negotiations with the Cree and Inuit of Quebec in 1973, when an ambitious hydroelectric project was temporarily halted by a Quebec court that recognized an Aboriginal interest in land. ${ }^{112}$ Although the initial case was overturned a few days later, ${ }^{113}$ the governments and the Indigenous parties signed the first modern treaty in $1977 .{ }^{114}$ Since then there have been about a dozen other treaties signed in British Columbia, the Yukon, the Northwest Territories, Nunavut, and Labrador, covering, in total, 40 per cent of Canada's lands, waters, and resources. ${ }^{115}$ In other words, the Crown has embarked on a modern treaty-

${ }^{111}$ For a discussion of impact benefits agreements, see IBA Research Network, at www.impactandbenefit.com/ (accessed 22 December 2014). The Impact Benefit Agreements are not without problems, including issues related to power imbalance and lack of transparency: See K.J. Caine and N Krogman, "Powerful or Just Plain PowerFull? A Power Analysis of Impact and Benefit Agreements in Canada's North", 2010 Organization \& Environment, 23(1): 76-98.

${ }^{112}$ Gros-Louis v Société de développement de la Baie James (1973), 8 C.N.L.C. 188).

113 James Bay Development Corp. v Kanatewat (1973), 8 C.N.L.C. 414; and Société de développement de la Baie James v Kanatewat (1974), 8 C.N.L.C. 373.

114 James Bay and Northern Quebec Agreement, 1977, at www.gcc.ca/pdf/LEG000000006.pdf. For a general description of this agreement, see Shin Imai, "Land Claims in Canada" in Handbook of the North American Indians, Volume 2, pp. 177-184 (Washington D.C.:Smithsonian Institute, 2007).

${ }^{115}$ For a listing and description of agreements see Aboriginal Affairs and Northern Development Canada, Final Agreements and Related Implementation Matters, at https://www.aadnc-aandc.gc.ca/eng/1100100030583/1100100030584 (accessed 27 December 2014). For a perspective from the First Nations parties to these agreements, see Land Claims Coalition, at www.landclaimscoalition.ca/ (accessed 27 December 2014). 
making exercise that, like the historic treaties, recognizes the existence of an Indigenous collectivity, recognizes their interest in their land, and recognizes the necessity of obtaining consent to access their territory.

Until the Crown institutes comprehensive negotiations on treaty lands, the issues relating to a meaningful right to harvest will continue to be presented in the courtroom. At the present time, courts have not developed a framework nor a forum for discussing this issue. It cannot be raised before the exploration phase because there are not impacts. It cannot be raised during the assessment phase or the exploration phase because only the impacts of the specific project can be considered. And even if treaty infringement is proved, deep consultation is sufficient to allow the project to proceed.

I argue that courts can find a way out of this morass using the existing framework developed in Sparrow and recognizing that new resource extraction activities on treaty lands could result in treaty infringement. In analyzing justification for the Crown conduct, courts could start developing the concept of consent first mentioned by the Supreme Court of Canada in Delgamuukw v. British Columbia. By doing this, courts will encourage the Crown to negotiate early and perhaps push the Crown to develop a broad process for setting aside treaty lands to fulfill the treaty promises.

\section{Concluding Thoughts}

Having argued for the adoption of the consent standard, I realize that these preliminary ideas cannot be implemented without a great deal of refinement. I will point out four important policy issues that need further consideration. 
First, the contemporary status of the land may have an impact on the implementation of the consent standard. Unoccupied Crown land would be relatively straightforward to bring into the consent framework, but lands that have already been "taken up" for extractive industries, or lands that have already been alienated to third parties, would raise complicated discussions on how to addressnon-Indigenous interests.

Second, the precise circumstances that would trigger the necessity of consent would have to be worked out in the Canadian context. Opinion at the international level suggests that consent would not have to be sought on every decision that could affect Indigenous land interests. However, the articulation of what "significant" impact would attract the requirement for consent should be developed through the consideration of specific cases.

Third, there would have to be some thought put into what "hunting, fishing, and trapping" means in the context of the land as a source of livelihood today. Are these words to be read narrowly, to encompass only subsistence harvesting activities? In my 2001 article, I argued that the harvesting rights recognized in treaties should not be seen as rights of individual Indians, but rather as a guarantee of collective survival. ${ }^{116}$ That is, the Crown must ensure that there are sufficient resources on treaty lands to provide for the survival of the collective as a whole. Although the words in the treaty seem to be limited to individual rights to harvest from the land, a more historically accurate reading would see that the harvesting rights were a recognition that the Indigenous parties relied on the land for their economic survival. This economic survival approach is supported in

${ }^{116}$ Supra note 102. 
the Supreme Court of Canada's decision in $R . v$ Marshall. ${ }^{117}$ In this case Donald Marshall, a Mi'kmaq in Nova Scotia, was acquitted of fishing and selling eels without a licence. The Court interpreted a 1760 treaty, which did not mention fishing at all but had a clause providing for commercial relations between the British and the Mi'kmaq. As there was evidence that fish were traded at the time of the treaty, the Court found that the trading clause meant to protect "access to the things that were to be traded." In other words, the Court took into account the larger economic context of the Indigenous relation to the land.

Fourth, would the consent standard permit a First Nation to authorize hazardous activities, such as nuclear waste dump on its lands? In other words, does the ability to prevent deleterious activity also provide the Indigenous group an ability to authorize activity that would have a significant impact on its lands? I would say "no," because the ability of a First Nation to authorize activities on its lands involves governance issues that are addressed in the self-government and land claims agreements mentioned above. ${ }^{118}$ The consent standard does not itself address governance issues. It has been applied at the international level as a shield against detrimental extractive projects on Indigenous lands, not as a sword that can give authority to Indigenous groups. Both Delgamuukw and Xeni Gwet'in say that Indigenous people may not permit uses on their lands that would be inconsistent with the foundation of the Indigenous connection to the land and the interests of future generations. It seems to me, then, that in Canada, adopting the free, prior,

${ }^{117}$ R. v Marshall, [1999] 3 SCR 456.

${ }^{118}$ See text at n 115. 
informed consent standard will not open the way for unregulated deleterious uses of Indigenous lands.

If there were treaty negotiations, these four questions would be an important part of the discussions. Absent such negotiations, the issues will be addressed in the courtroom. At the present time, courts in Canada are lagging behind international and private industry standards, as well as practice on the ground. Rather than focusing on the fact that Indigenous parties do not have a veto, courts should focus on the development of the concept of consent. 